\title{
CHANGE MONITORING OF THE DNIPRO RIVER WITHIN KYIV USING SATELLITE INFORMATION
}

\author{
$1^{*}$ Olha Tomchenko, ${ }^{2}$ Roman Panchenko, ${ }^{2}$ Lyudmila Mazurkevich
}

${ }^{1}$ State institution "Scientific Centre for Aerospace Research of the Earth of the Institute of Geological Science of the National Academy of Sciences of Ukraine", Kyiv, Ukraine

${ }^{2}$ Rusanovsky Lyceum, Kyiv, Ukraine

*Corresponding author: tomch@i.ua

\begin{abstract}
The dynamics of overgrowth of aquatic vegetation of the Dnipro River within the city of Kyiv in the period from 2005 to 2017 was studied using satellite information and ground data and a causal relationship between climate change and overgrowing processes was established. Based on the results of systematization and the analysis of the land hydrological data obtained in the archives of the CGO SESU of Ukraine, the graphs showing the dynamics of changes in average annual air temperature and water temperature, water level, its expenses within Kyiv were constructed. Investigating the influence of climatic factors, it was found that the temperature of the summer months has risen by about $2^{\circ} \mathrm{C}$ over the last decade. It is assumed that the change of this factor leads to the change and destruction of the hydrological regime of the river. First of all, the flow velocity, the average annual water temperature, the total runoff volume, the evaporation volume from the Dnipro River surface and others change. This changes, together with the influence of major anthropogenic factors leads to the progress of overgrowth and «algal blooms» of the river. It is established that during the period from 2010 to 2017, the area of overgrown Dnipro River within Kyiv increased more than 2 times, and was already $2.1 \mathrm{~km}^{2}$, which is $7.5 \%$ of the total water surface. It was found that the largest areas of overgrowth are in small bays and straits of the Dnipro River, for the period from 2005 to 2017 the percentage of overgrowth of the water surface in the bays increased and amounted to $14.5 \%$, which is almost 5 times more than in 2005.
\end{abstract}

Key words: overgrowth of aquatic vegetation; algal blooms; satellite information; state of the reservoir; Dnipro River. 


\section{Introduction}

The problem of changing in the natural ecosystem of Dnipro River and the impact of anthropogenic and climatic factors on it are two of numerous serious problems of the present. The Dnipro basin is the country's main waterway and supplies about $70 \%$ of Ukraine's population with water Recently, the river has undergone negative processes that significantly impair water quality, affect the environment and human health. In particular, these are the processes of shallowing of the reservoir overgrowth of aquatic vegetation, which are progressing every year.

Now it is difficult to present researches of water resources of Earth without materials of the remote sensing (RS) and geoinformation (GIS) technologies. With the help of analysis of space images, you can not only get an idea of the state of watercourses, individual reservoirs, watershed basins but also assess their ecological status. The main advantages of using space images are simultaneous coverage of a large area of water for a certain period of time, the continuity of the information content of the image for each point of the image, high frequency of data for analysis.

The purpose of the study is to identify the causes and dynamics of changes in overgrowth of higher aquatic vegetation based on the recognition of space images, to determine the main factors influencing this process, to establish their relationship and impact on water quality.

The main hypothesis in the work was that the deterioration of water quality is a consequence of the influence of increasing ambient This increase increases the water temperature of the river and directly influences its algal blooms and hydrological parameters such as flow velocity, water flow, evaporation from the surface, etc.

Based on the analysis of previous studies, such scientists as Butenko O.S., Berezina S.I., Krasovsky G. Ya. Shumakov F.T., Vyshnevsky V.I., Shevchuk S.A. (Vyshnevskyi 2018) made a significant contribution to the development of methods of processing and thematic interpretation of space images to assess the quality of surface waters. However, today the determination of water quality by remote sensing of Earth (RSE) is often reduced to a visual assessment of water overgrowth. Methods aimed at assessing the quality of water bodies, such as colour, turbidity, transparency, temperature are perspective.

The materials of RS, statistics of the ground observations, namely materials of Central Geophysical Observatory of B. Sreznevsky (CGO) were used to solve these tasks. So, in particular, in CGO archive it was received and analyzed changes of average monthly air temperature and water during the summer period (from July to August) from 2005 to 2019 and expenses and changes of water levels of Dnipro River within Kyiv. Also, average annual values of hydrochemical indicators, such as, by $\mathrm{O}_{2}, \mathrm{NO}_{2}^{-}, \mathrm{NO}_{3}^{-}, \mathrm{NH}_{4}^{+}, \mathrm{P}, \mathrm{SO}_{4}{ }^{2-}, \mathrm{Cl}^{-}, \mathrm{Cr}^{4+}, \mathrm{Cu}^{+}, \mathrm{Fe}^{+}$, oil products, phenols, biochemical (biological) oxygen demand (BOD) from 1986 to 2016 were analyzed. 
To trace the temporal dynamics of the reservoir (in our case to compare the change in the area of overgrowth on the river surface) we used space images of high spatial resolution for three-time slices 2005 - 2010 - 2017 in the summer (July-August) when the vegetation mass of aquatic vegetation the largest.

Space images obtained in different spectral ranges served as a real cartographic basis, which provides extrapolation of information obtained from ground-based observations. Such an approach using integrated informative indicators opens new opportunities for identifying general trends of changes in aquatic ecosystems and can form the basis of comprehensive monitoring of water bodies and their catchments at a qualitatively new level (Tomchenko, Khyzhnyak 2019).

The influence of various factors on the status of the river, in particular on its hydrological regime, was analyzed. Of the climatic and anthropogenic factors, the most influential ones have been identified to date. The scheme of interaction of these factors was made (Fig.1).

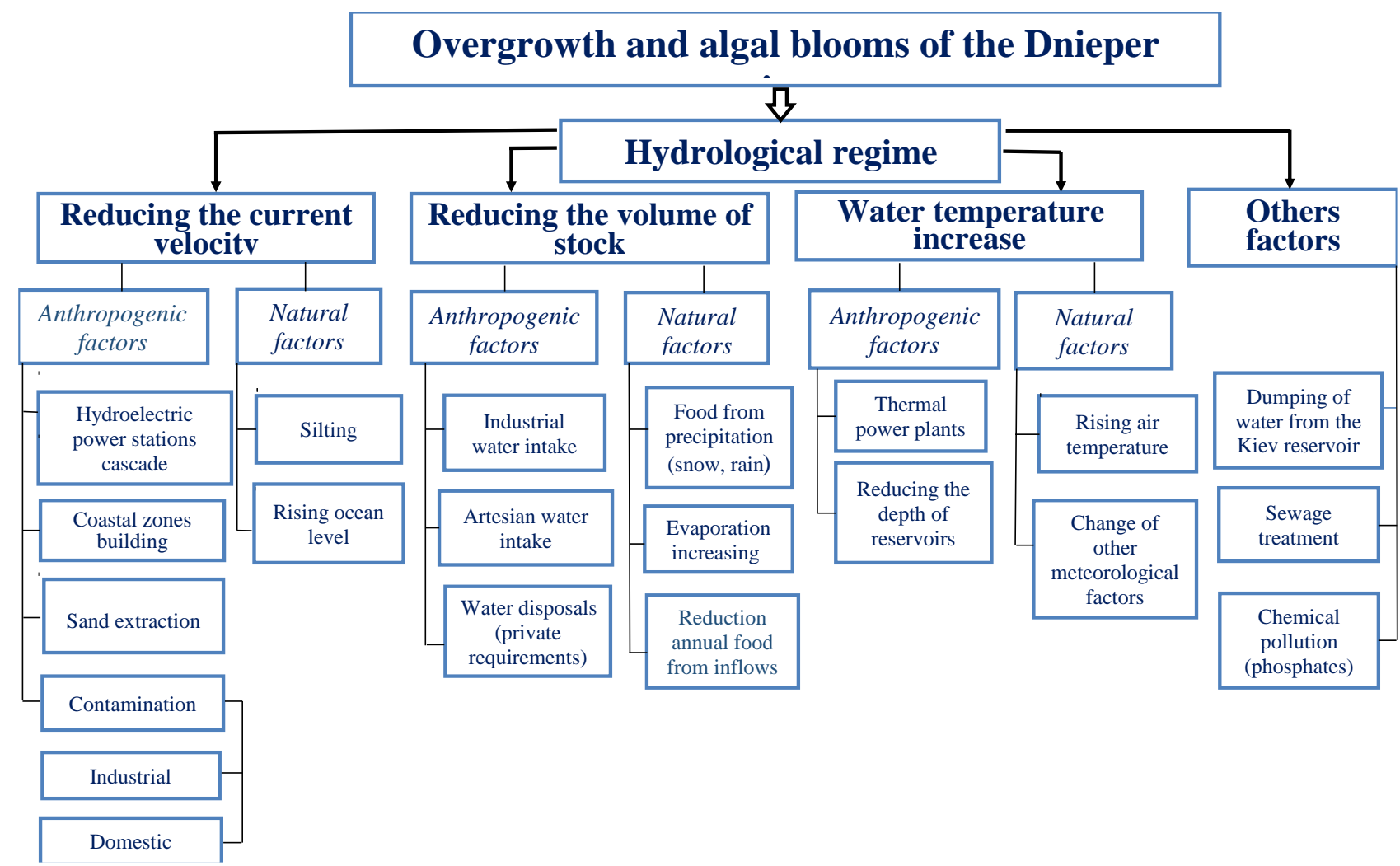

Fig. 1. The scheme of factors influencing the process of overgrowing and algal blooms of the Dnipro River.

\section{Results and discussion}

Water objects are difficult ecosystems which analysis happens on the basis of the generalized criteria to comprehensive accounting of their components (landscape complexes, hydrological, 
geological, hydrobiological and hydrochemical characteristics) and influences of climatic factors. The climatic factor includes the influence of a number of factors, in particular, such as changes in temperature, wind speed, precipitation, time of solar radiation and others. Significantly increasing the impact on overgrowth and algal blooms over the past 20 years have been an increase in air temperature. Increase in air temperature directly influences the increase in water temperature in the river. First of all, the temperature in places with a small depth increases - to 1 - 1.5 meters. As a rule, it is a coastal zone, floodplains and bays, reservoirs. The dynamics of changes in the average annual water temperature in Kyiv over the past 20 years is shown in the graph (Fig. 2). The main summer months of the beginning of overgrowing with aquatic vegetation and the peak of the process of algal blooms of water - June and August - are taken for analysis.

The temperature of the reservoir is directly related to the physical (hydrological) parameters of the river, such as water flow, flow velocity, etc.

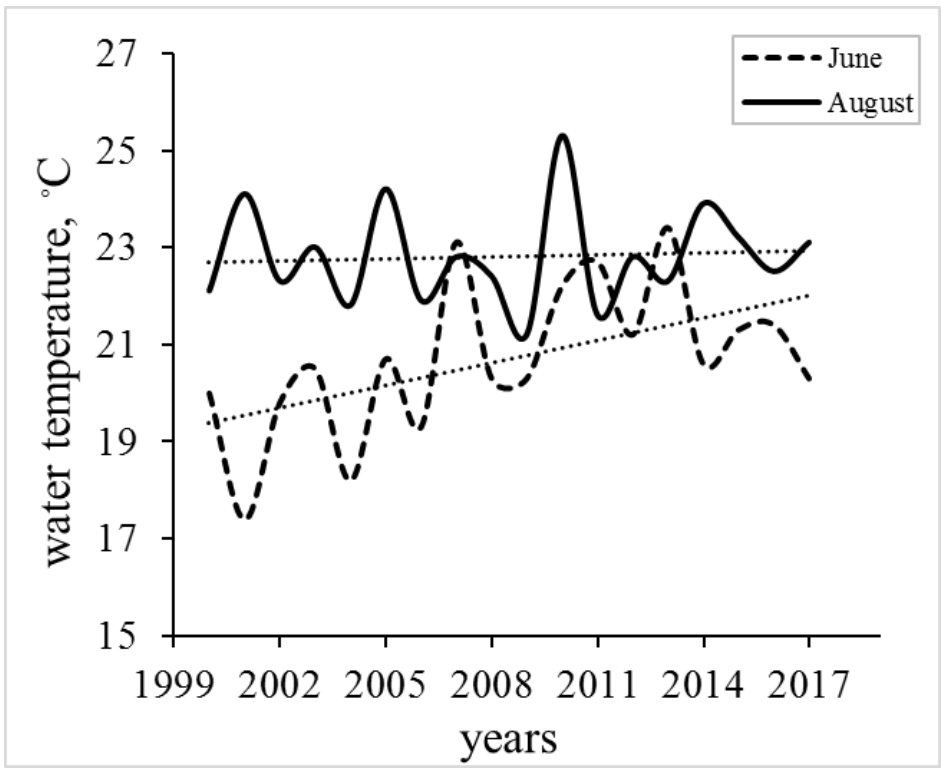

Fig. 2. Diagram of changes in the average monthly (June, August) temperature of the Dnipro water in Kyiv in the summer from 2000 to 2017.

Since reservoirs have the largest evaporation area and the lowest flow velocity, they are the ones that reflect the processes of evaporation, overgrowth and algal blooms. It reduces their volume and area. In particular, the area of the Kyiv Reservoir today is already $823.7 \mathrm{~km} 2$ [2], it has decreased by almost $100 \mathrm{~km} 2$ since 1965 . The annual decrease is approximately $2 \mathrm{~km}^{2}$. This indirectly affects the water level, in particular within Kyiv. Thus, in the hottest months there is a decrease in the water level at the observation post near Kyiv. According to the data obtained from the CGO, graphs were constructed to show the dynamics of changes in the level and flow of water (Fig.3). 


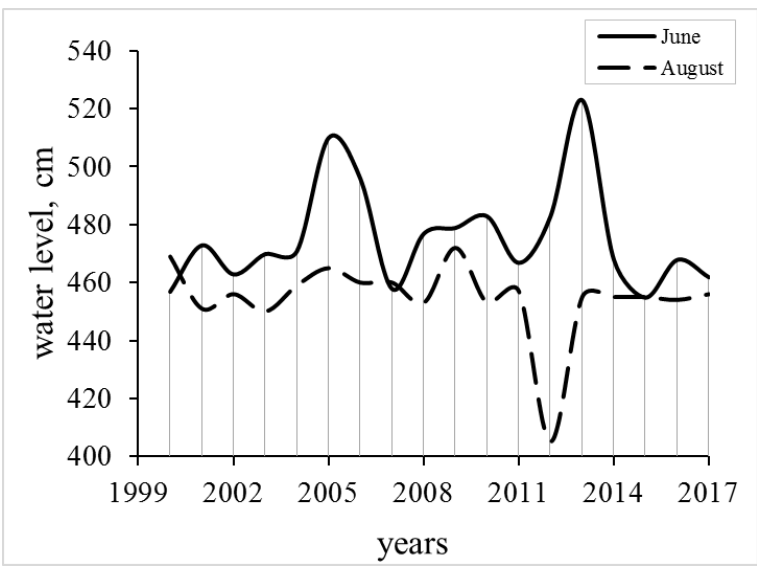

$a$

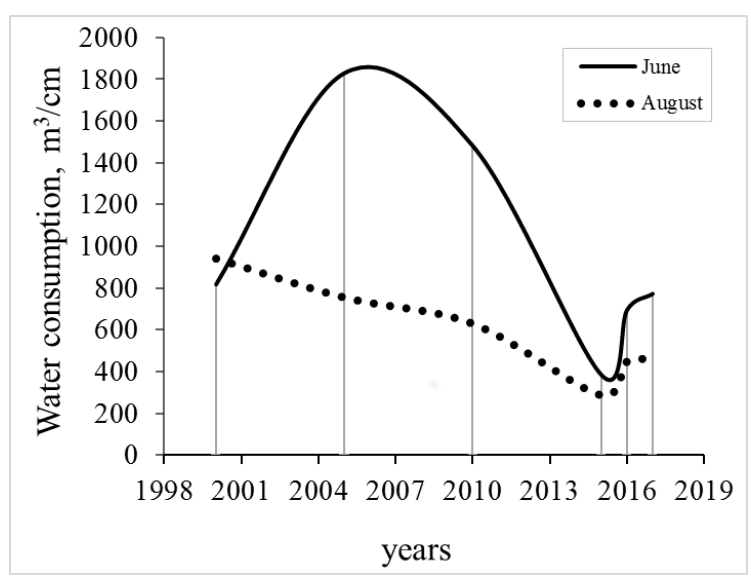

$b$

Fig. 3. Dynamics of change of hydrophysical indicators of the state of the Dnipro River at the Kanivske-Kyiv observation post: dynamics of water level change $(a)$, water flow $(b)$.

The analysis of existing terrestrial hydrochemical observations revealed the following trends. It is accurately expressed dynamics of increase in concentration of the general iron in the last 10 years. It is known that being a biologically active element, iron to some extent affects the intensity of phytoplankton development and the qualitative composition of the microflora in the reservoir. There is also an increase in the concentration of nitrate nitrogen, which may be caused by an increase in anthropogenic eutrophication of the river. In addition, there is a decrease in oxygen concentration, which also has a negative impact on the life of aquatic organisms (Tomchenko 2017). Of the positive trends can be noted a decrease in the concentration of chlorides (Fig. 4).

Space information RSE is the main source of information used in the study of changes in the area of aquatic vegetation of the Dnieper. A program was used to analyze the areas of increase in river water vegetation is «Google Earth Pro» and EO Browser resource. 


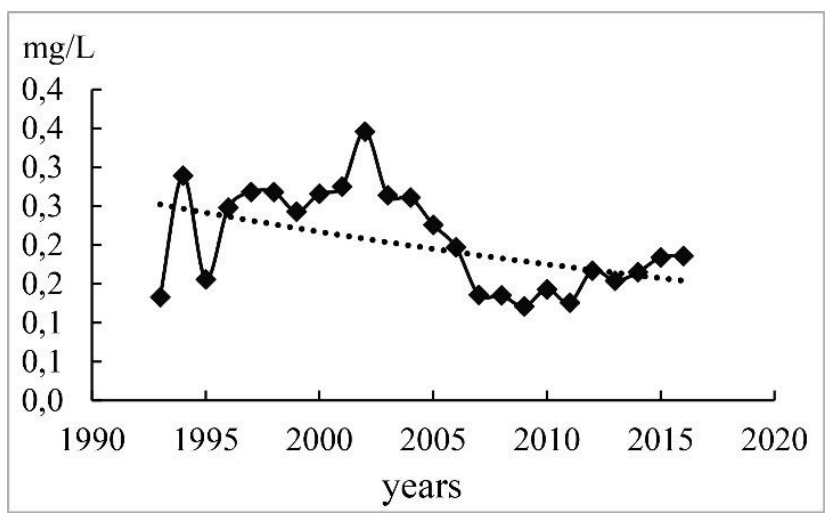

$a$
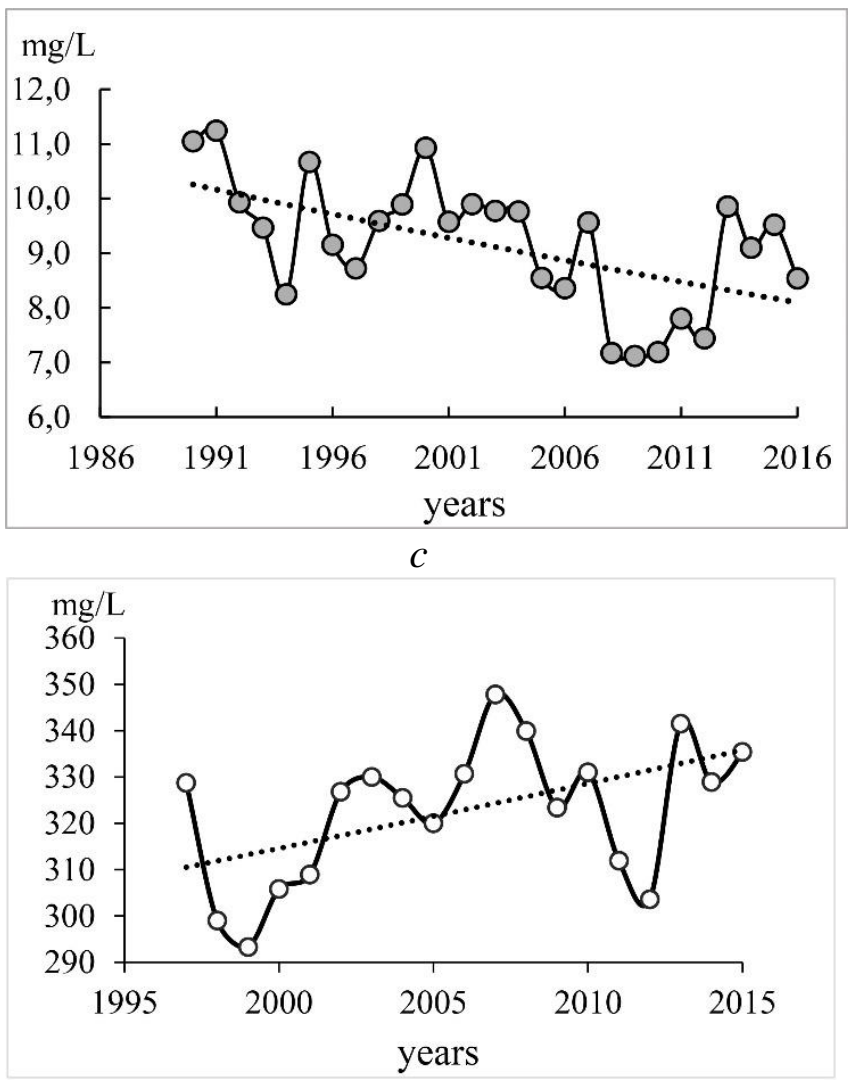

$e$
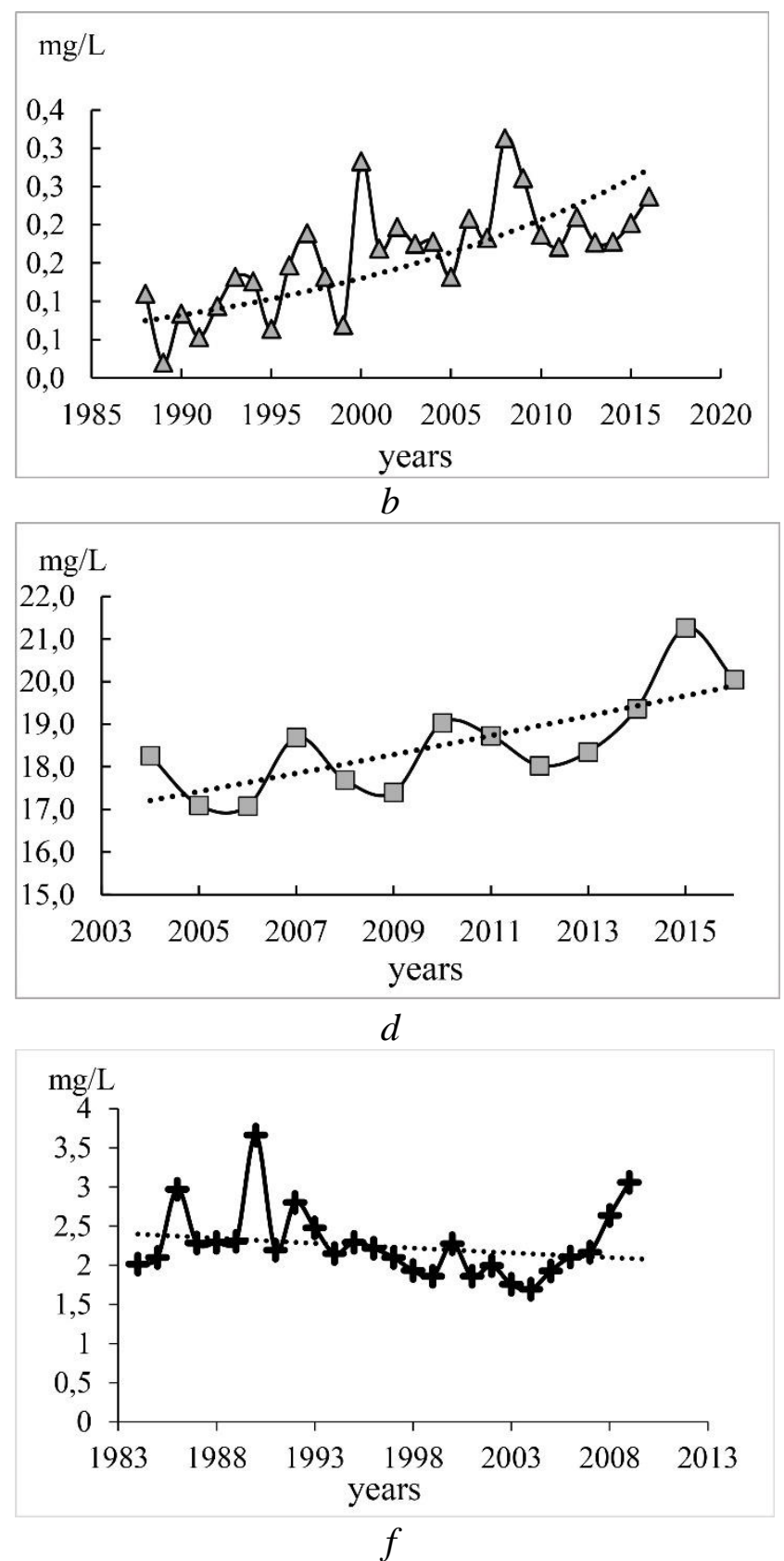

Fig. 4. Long-term dynamics of hydrochemical indicators of water quality in the Dnipro River within Kyiv: $\mathrm{P}(a), \mathrm{NO}_{3}{ }^{-}(b), \mathrm{O}_{2}(c), \mathrm{Fe}(d), \mathrm{SO}_{4}(e), \mathrm{BOD}(f)$.

Remote sensing is the main source of information used in the study of changes in the area of aquatic vegetation of the Dnipro. A program was used to analyze the areas of increase in river water vegetation is «Google Earth Pro» and EO Browser resource. In the historical space imagery view, areas of overgrowth were visually identified and manually delineated by their boundaries for further area calculation and comparative analysis of changes from 2005 to 2017 (Fig.5-6) in the summer were selected (July-august) when the vegetative mass of aquatic vegetation is greatest.

At fig.5-6 space images with examples of the dynamics of increasing overgrowth of higher aquatic vegetation in the Dnipro region between the Paton and South bridges are presented After all, it is in this area that we observe an increase in shoals, in particular in fig. 6 shows a shoal that is likely to 
soon become a full-fledged island. On Dnipro River within Kyiv the process of overgrowing by the highest water vegetation is caused by distribution of such main types of vegetation as: Typha and Phragmites australis; Trapa natans and Nymphaea; Elodea canadensis and Salvinia natans.

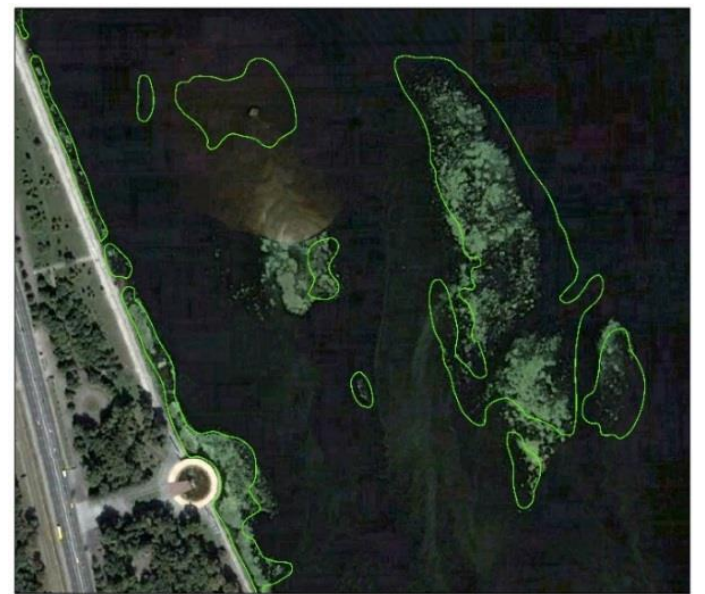

21.08 .2005

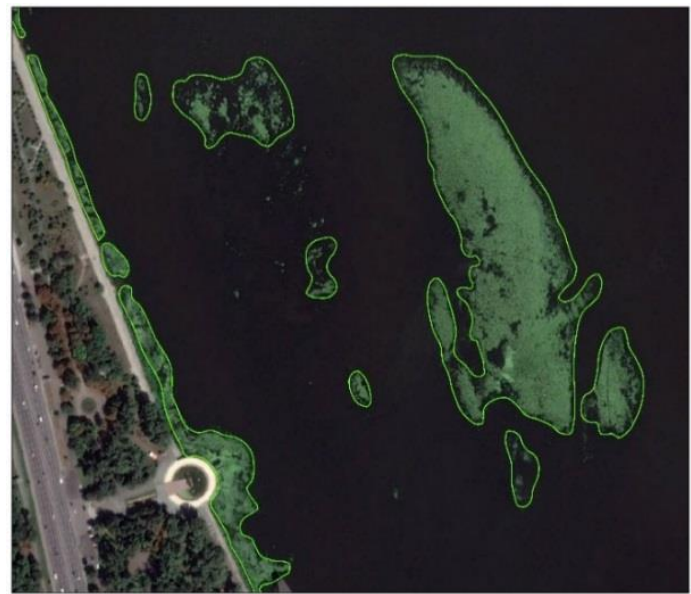

09.08.2017

Fig. 5. Examples of the dynamics of overgrowing of the Dnipro River with higher aquatic vegetation north of the Paton Bridge, opposite the monument to the founders of Kyiv.

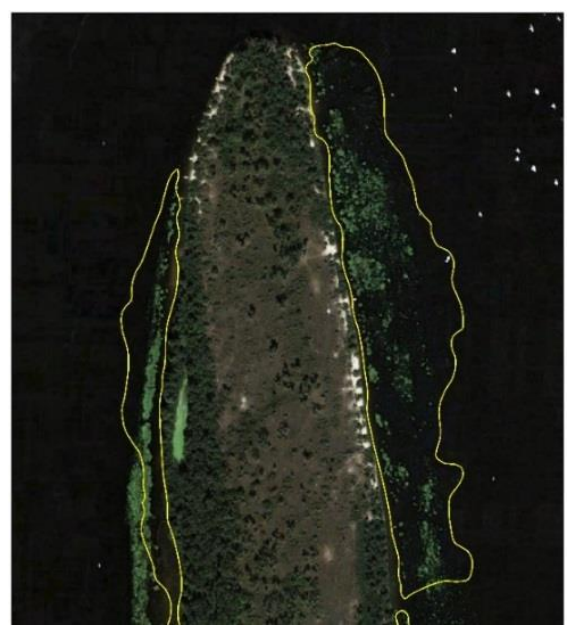

21.08.2005

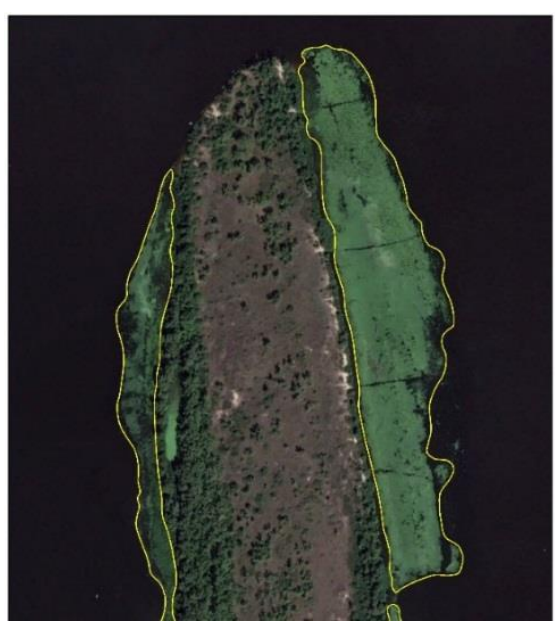

09.08.2017

Fig. 6. Examples of the dynamics of overgrowing of the Dnipro River (Telychka sleeves) with higher aquatic vegetation in the northern part of the Velykyi island.

Table 1 was created, comparing the areas of overgrown areas of aquatic vegetation of the Dnipro River, according to the calculations of the main channel and its bays, straits within Kyiv for the period from 2005 to 2017, their percentage of water surface area. 
Table 1. Comparative characteristics of the areas of overgrowth of the Dnipro River within the city of Kyiv in the period from 2005 to 2017

\begin{tabular}{|c|c|c|c|c|c|c|}
\hline \multirow{2}{*}{} & \multicolumn{2}{|c|}{2005} & \multicolumn{2}{c|}{2010} & \multicolumn{2}{c|}{2017} \\
\cline { 2 - 7 } & $\mathrm{km}^{2}$ & $\%$ & $\mathrm{~km}^{2}$ & $\%$ & $\mathrm{~km}^{2}$ & $\%$ \\
\hline Dnipro River main course & 0.54 & 2.3 & 0.69 & 2.88 & 1.49 & 6.32 \\
\hline Dnipro River Bays/strait & 0.14 & 3.51 & 0.21 & 5.26 & 0.58 & 14.54 \\
\hline Total area & 0.68 & 2.47 & 0.9 & 3.23 & 2.07 & 7.51 \\
\hline
\end{tabular}

On the maps of 2005, the area of overgrowth of the main channel of the Dnipro River was 0.54 $\mathrm{km} 2$, in percentage terms $-2.3 \%$ of the water surface area of the channel. For the period from 2005 to 2010 it is already $2.88 \%$. In the following years, the overgrowing process increased rapidly and in August 2017 was already 6.32\%.

The areas of water vegetation overgrowth of the water surface of all bays and straits of the Dnipro River within Kyiv in the period from 2005 to 2017 were calculated, also was created a comparative table 2 .

Table 2. Comparative characteristics of the overgrown areas of the Rusanivs'ka strait and the Dnipro bays within the city of Kyiv from 2005 to 2017

\begin{tabular}{|c|c|c|c|c|c|c|c|c|}
\hline \multirow{3}{*}{ \# } & \multirow{3}{*}{$\begin{array}{c}\text { Name of the bay } \\
\text { or strait }\end{array}$} & \multirow{3}{*}{$\begin{array}{c}\text { Bay/strait water } \\
\text { surface area } \\
\text { (ha) }\end{array}$} & \multicolumn{6}{|c|}{ Areas of overgrowth of aquatic vegetation } \\
\hline & & & \multicolumn{2}{|c|}{2005} & \multicolumn{2}{|c|}{2010} & \multicolumn{2}{|c|}{2017} \\
\hline & & & (ha) & $\%$ & (ha) & $\%$ & (ha) & $\%$ \\
\hline 1 & Sobache Hyrlo & 81.2 & 0.98 & 1.21 & 0.93 & 1.15 & 5.77 & 7.11 \\
\hline 2 & Obolon' & 54.4 & 0.81 & 1.49 & 2.07 & 3.81 & 7.91 & 14.54 \\
\hline 3 & Matviyivs'ka & 56.3 & 2.35 & 4.17 & 4.48 & 7.96 & 9.82 & 17.44 \\
\hline 4 & Berkovshchyna & 22 & 0.2 & 0.9 & 0.3 & 1.36 & 1.67 & 7.59 \\
\hline 5 & Dniprovs'ka & 4.1 & 0.1 & 2.44 & 0.14 & 3.41 & 0.97 & 23.66 \\
\hline 6 & Halerna & 21.8 & 0.83 & 3.8 & 1.33 & 6.1 & 2.94 & 13.49 \\
\hline 7 & Staryk & 37.5 & 2.34 & 6.24 & 3.61 & 9.63 & 4.81 & 12.83 \\
\hline 8 & Rusanivs'ka & 121.65 & 6.57 & 5.4 & 7.82 & 6.43 & 24.5 & 20.14 \\
\hline
\end{tabular}

According to the results of calculations, in 2005 the best condition was in the bays of Berkovshchyna and Sobache Hyrlo. Their percentage was $0.9 \%$ and $1.21 \%$, respectively. The largest percentage of shallow areas were in the bays of Staryk - $6.24 \%$ and Rusanivs'ka Strait - 
5.4\%. In 2010, the largest area of overgrowth remained in the Stary`k Bay - 3.61 hectares (9.63\%) and the Rusanivs'ka Strait - 7.82 hectares (6.43\%). However, this area almost did not increase in the period from 2005 to 2010 in the Berkovschyna Bay. This is due to the fact that during this period it was artificially washed of sand for construction, which hindered the development of the overgrowing process. According to the results of the study, it can be said that increasing the temperature accelerates the processes of overgrowth and algal blooms with the dying and decay of algae. This leads to the release of toxic substances into the water, changes the hydrological regime of the river.

Also, keeping track of today's data on air temperature, rainfall, pollution status, etc. it is possible to predict further deterioration of water quality and the overall environmental status of the river. So, summer of 2020 this deterioration can follow as a result of the current loss of snow food and further global growth of temperature.

In the perspective of further research, we see the establishment of the relationship between the indicators of remote assessment of the Dnipro River within the city of Kyiv with the indicators of ground research to model their impact on the overall condition of the reservoir. To create a further forecast assessment of changes in their ecological status, we propose to use the mathematical apparatus of the $\mathrm{ABC}$ method, which is based on taking into account the causal relationships between the modules of a complex system. The quality of the forecast will be determined by the correspondence of the links of the linear model between the known data and the forecast states or processes.

\section{Conclusions}

GIS monitoring of water bodies based on remote sensing data and land statistics allows not only to monitor the state of water bodies, but also to predict changes in their ecological situation and develop a balanced management and action plan for public services.

According to the results of the research, the most intensive development of the process of overgrowing with higher aquatic vegetation was in the period from 2010 to 2017. During this time, the area of shallow areas of the Dnipro River within the city of Kyiv has more than doubled and was already $2.07 \mathrm{~km} 2$, which is $7.5 \%$ of the total water surface. The main factors influencing to the water quality in the Dnipro River are temperature and hydrological regime. Comparing the dynamics of changes in water temperature, the dynamics of changes in water flow, the area of overgrowth, we can confirm the interdependence of these phenomena. Unfortunately, it is almost impossible to change the tendency to increase the temperature. Therefore, to improve the water quality of the river, we recommend taking the following measures: pay special attention to reducing the amount of phosphate-containing chemicals entering to the river with wastewater; to clean the 
coastal strip; concreting of shores; increase water level due to small rivers; reduce the development of coastal areas, etc.

\section{Reference}

Fedorovsky A. D., Khyzhnyak A. V., Tomchenko O. V., Zub L. N., Podgorodetska L.V., Dyachenko T. N., Shevchenko A. N., Vlasova E. V., Khodorovsky A. Ya., Yakymchuk V. H. "The multidisciplinary analysis of the aerospace and ground information while assessing the status of water ecosystems based on the methods of system analysis". Ukrainian journal of remote sensing, 2015, 7, 27-42. [in Ukraine]

Shchorichnyk yakosti poverkhnevykh vod Ukrainy za danymy derzhavnoi systemy sposterezhen hidrometsluzhby. Basein Dnipra. K.: UOP Ukr HMTs, 1986-2016. [укр. мова]

Tomchenko O., Mazurkiewicz L., Malets A., Pidlisetska I. "Research of the change dynamics of the area of Kyiv group of islands of the Dnieper". Bulletin of Taras Shevchenko National University of Kyiv, Geography, 2019, 1 (73), 55-62. [in Ukraine]

Tomchenko O.V., Khyzhnyak A.V. "HIS monitorynh rekreatsiinoho navantazhennia na vodni resursy m. Kyieva". Heoinformatsiini tekhnolohii u terytorialnomu u pravlinni ta ekspertnykh doslidzhenniakh: pravovi. orhanizatsiini. Tekhnichni problemy: materialy IV mizhnar. nauk.prakt.konf. Lviv: Vydavnytstvo Lvivskoi politekhniky, 2017, 163-166. [укр. мова]

Tomchenko O.V., Manko D.I. "Suputnykovyi monitorynh skupchen planktonnykh vodorostei («tsvitinnia» vody)". Aerokosmichni tekhnolohii v Ukraini: problemy ta perspektyvy, tezy dopovidei III naukovo-praktychnoi konferentsii, Kyiv. 2019, 86-87. [in Ukraine]

Shchorichni dani pro rezhym ta resursy poverkhnevykh vod sushi. Tsentralna heofizychna observatoriia im. B.Sreznevskoho DSNS Ukrainy, Derzhavnyi arkhiv TsHO. Derzhavnyi vodnyi kadastr. 2005-2019 [in Ukraine]

Vyshnevskyi V.I., Shevchuk S.A. "Vykorystannia danykh dystantsiinoho zonduvannia Zemli u doslidzhenniakh vodnykh obiektiv Ukrainy". Kyiv: Interpres LTD, 2018. [in Ukraine]

Received 21.07.2020

Revised 18.09.2020

Accepted 23.09.2020 


\title{
МОНІТОРИНГОВЕ ДОСЛІДЖЕННЯ ЗМІНИ ДНІПРА В МЕЖАХ КИЄВА З ВИКОРИСТАННЯМ СУПУТНИКОВОЇ ІНФОРМАЦЇ̈
}

\author{
${ }^{1 *}$ О. Томченко, ${ }^{2}$ P. Панченко, ${ }^{2}$ Л. Мазуркевич
}

1 Державна установа «Науковий центр аерокосмічних досліджень Землі Інституту геологічних наук Національної академії наук України», Київ, 01054, Україна.

${ }^{2}$ Русанівський ліцей, Київ, 02147, Україна.

*Автор для листування: tomch@i.ua

\section{Реферат}

В роботі за допомогою космічної інформації та наземних даних досліджено динаміку заростання водною рослинністю р. Дніпро в межах м. Києва в період з 2005 по 2017 рік та встановлено причинно-наслідковий зв'язок між кліматичними змінами та процесами заростанням. За результатами систематизації та аналізу наземних гідрологічних даних отриманих в архіві ЦГО ДСНС України, були побудовані графіки, що відображають динаміку змін середньорічної температури повітря та води, рівня води, її витрати в межах Києва. Досліджуючи вплив кліматичного фактору, виявлено, що температура літніх місяців за останнє десятиріччя піднялась приблизно на $2^{\circ} \mathrm{C}$. Саме зміна цього фактору у напрямку збільшення, на теперішній час, найбільше призводить до зміни та руйнації гідрологічного режиму річки. В першу чергу змінюються такі основні характеристики Дніпра, як швидкість течії, середньорічна температура води, загальний об'єм стоку, об'єм випаровування 3 поверхні та інші. Їх зміна, разом з впливом основних антропогенних факторів призводить до прогресу процесів заростання і «цвітіння» води річки. Тільки за період з 2010 по 2017 рік площа заростання Дніпра в межах Києва зросла більш ніж у 2 рази, і становила вже 2,1 км², а це 7,5\% від всієї поверхні води. Завдяки виконаному дослідженню було виявлено, що найбільші площі заростання знаходяться у невеликих затоках та протоці Дніпра. За період 3 2005 по 2017 рік відсоток заростання поверхні води у затоках значно виріс і складав 14,5\%, а це майже у 5 разів більше, ніж у 2005 році.

Ключові слова: заростання водною рослинністю; цвітіння води; супутникова інформація; стан водойми; Дніпро. 